\title{
Curry Leaves: A Promising Ingredient for the Development of $\beta$-Carotene Rich Upma
}

\author{
Sonia, Varsha Rani*, Sangeeta C. Sindhu and Josephine John \\ Department of Foods and Nutrition, CCS Haryana Agricultural University, Hisar, India \\ *Corresponding author
}

\begin{abstract}
A B S T R A C T
This study was undertaken to develop and analyze $\beta$-carotene rich upma supplementing with curry leaves powder $(5,7.5$ and $10 \%)$. Leaves were blanched for 15 seconds and dried using freeze drier. Developed upma were subjected to sensory evaluation by a panel of semi-trained judges. Proximate composition, dietary fibre and $\beta$-carotene were analysed in developed upma. Data was statistically analysed using SPSS and OPSTAT software. Blanching of curry leaves up to 15 seconds was found suitable for proper retention of colour. Freeze drying was found suitable for the retention of $\beta$-carotene. Upma prepared by incorporating 7.5 per cent of CLP was more acceptable as compared to the one that containing 10 per cent CLP. Results revealed that the protein content of control upma was 11.10 per cent which increased significantly up to 12.07 per cent with incorporation of CLP. Crude fibre and ash content in upma supplemented with CLP had increased significantly as compared to control upma. Total dietary fibre content ranged from 20.48 to 23.70 per cent in supplemented upma whereas control upma contained 19.14 per cent. $\beta$-carotene content of $\mathrm{T}_{3}$ upma $(9528.28 \mu \mathrm{g} / 100 \mathrm{~g})$ was highest followed by $\mathrm{T}_{2}, \mathrm{~T}_{1}$ and control upma which was 30 to 60 times higher than $\beta$-carotene concentration of control upma.
\end{abstract}

\section{Introduction}

The spice Curry Leaf (Murraya koenigii) is considered as a sub- tropical to tropical belonging to the family Rutaceae. Curry leaf tree, is a native to Sri Lanka, India and other Asian countries (Kumar and Reddy 2013) and available at very low cost. Among fourteen global species of genus Murraya, only Murraya Koenigii (Spreng.) and Murraya Paniculata (Linn.) are available in India (Nayak et al., 2010). The curry leaf stem is dark green to brownish colour and has small spreading shrub which is about 2.5 meters in height (Jain et al., 2012; Singh et al., 2014). Curry plant is small and having highly aromatic and sweet smelling leaves. It possesses strong spicy and seasoning flavour with distinctive aroma. Considering the easy availability, low cost and nutritional quality of the curry leaves, various supplementary food products can be prepared with addition of leaves to utilize its potential and enhance product quality by improving its taste, aroma 
and increasing its energy, protein, dietary fiber, calcium, $\beta$-carotene and mineral content. Curry leaves has promising amount of $\beta$-carotene (preformed vitamin A) (Khoo et al., 2011). However, it was observed that the dehydrated curry leaves contain considerable amounts of oxalates and phytate phosphorous i.e. 501.55 and $86.52 \mathrm{mg} / 100 \mathrm{~g}$, respectively (Lal and Kaur, 2019) that might be a constraint in its utilization in products development. The main carotenoid, $\beta$ carotene depicts antioxidant activity. (Chandrika et al., 2010) and acts as free radical scavenger and singlet oxygen quencher (Jimenez-Escrig et al., 2000). It was reported to exert antioxidant effects in rats fed with high fat diet (Khan et al., 1997). Thus, curry leaf can prevent the formation of free radicals and maintain the tissues at normal levels (Khan et al., 1997). Curry leaves are having slightly stiff texture, because of that these generally discarded from the food during eating and hence the nutritional potential remains underutilized. To confirm maximum consumption of curry leaves one way is to use as dried form and it is used from the past to preserve the leaves. So that, the incorporation of these green leaves in dried forms in the various foods especially the traditional foods, fermented foods, bakery and confectionary items can meet the demand of the generation. This paper reports the nutritional composition of $\beta$-carotene rich upma prepared by incorporating curry leaves powder (CLP).

\section{Materials and Methods}

\section{Development of curry leaves powder (CLP)}

Healthy leaves were separated from their stalks and to remove adhering dirt and impurities leaves were washed thoroughly for 2 times with normal tap water and one time with distilled water. The curry leaves were blanched in boiling water for 15 seconds and then immersed in chilled water immediately.
The leaves were then poured in petri dishes and kept in lyophilizer (ALPHA 1-4 LSC plus) at $-65^{\circ} \mathrm{C}$ under vacuum for 72 hours. It was then taken out and ground to prepare powder. The powder was then sieved to pass through 30 mesh sieve. The powder was stored in air tight food grade containers for further utilization.

\section{Standardization and sensory evaluation of upma}

For preparation of control upma, semolina $(100 \mathrm{~g})$, bengal gram $(5 \mathrm{~g})$, peanuts $(10 \mathrm{~g})$, capsicum $(5 g)$, beans $(5 g)$, carrot $(5 g)$, onion $(5 \mathrm{~g})$, coriander leaves, curry leaves and other spices were used. Semolina was replaced with 5, 7.5 and 10 per cent of CLP in experimental upma. It was evaluated for various sensory attributes by a semi-trained panel of 20 judges. Sensory evaluation of the prepared products was carried out to determine the most acceptable level of the curry leaves powder supplementation. The panellists were provided a proforma of 9 point hedonic scale for rating the upma in terms of appearance, colour, texture, aroma and taste. OAA scores were calculated on the basis of given scores to 5 sensory parameters.

\section{Nutritional analysis of upma}

All the control and CLP supplemented upma were oven dried to a constant weight at $60^{\circ} \mathrm{C}$, ground to a fine powder in an electrical grinder and analysed for various nutrients. Proximate composition including moisture, protein, fat, ash and crude fibre was analysed using standard methods (AOAC, 2010). Dietary fibre constituents were determined by using the enzymatic method given by Furda (1981). The samples of $\beta$-carotene were extracted according to the method given by Garcia-Plazaola and Becerril (1999) slightly modified by Chandra-Hioe et al., (2017) and were analysed in HPLC. 


\section{Results and Discussion}

As per the scores given to colour, appearance, aroma, texture and taste, the overall acceptability of upma was calculated and it was found that upma prepared by supplementing 7.5 per cent of CLP was most liked followed by $\mathrm{T}_{1}$ upma (Figure 1). Mean scores of OAA of control upma was 8.08 which fell in the category of 'liked very much'. Overall acceptability of $T_{1}, T_{2}$ and $T_{3}$ upma varied from 6.69 to 7.85 and consequently CLP supplemented upma were adjudged between 'liked slightly' to 'liked moderately'. It was observed that with the increased level of CLP, the scores of aroma, taste and texture of $T_{1}$ and $T_{2}$ upma were also increased whereas further increase in $T_{3}$ products turned down the scores significantly. However, the taste, aroma and texture of all the upma were within the acceptable range. Even the upma prepared with 10 per cent of CLP were found to be acceptable.

The contents of moisture, crude protein, crude fat, crude fibre, ash and total carbohydrates of $\mathrm{T}_{1}, \mathrm{~T}_{2}$ and $\mathrm{T}_{3}$ upma ranged from 42.62 to $44.78,11.44$ to $12.07,5.90$ to $6.25,1.77$ to $2.29,4.41$ to 4.97 and 30.63 to 32.16 per cent, respectively. Maximum contents of crude protein, crude fibre, ash and total carbohydrates were observed in $\mathrm{T}_{3}$ upma however, the maximum contents of moisture and crude fat were found in $\mathrm{T}_{1}$ upma (Table 1).

Soluble, insoluble and total dietary fibre content of control upma was found to be 4.6, 14.52 and 19.14 per cent, respectively. On the various levels of supplementation of curry leaves powder the soluble, insoluble and total dietary fibre content of upma was increased significantly $(P \leq 0.05)$. The contents of soluble, insoluble and total dietary fibre in curry leaves powder supplemented upma were ranged from 4.61 to $6.10,15.16$ to 17.60 and 20.48 to 23.70 per cent, respectively (Table 2).

Results presented in Table 3 indicated that the amount of $\beta$-carotene in control upma prepared with 100 per cent semolina was found to be $159.18 \mu \mathrm{g} / 100 \mathrm{~g}$. Curry leaves powder supplemented $\mathrm{T}_{1}, \mathrm{~T}_{2}$ and $\mathrm{T}_{3}$ upma had $4843.59,7185.89$ and $9528.28 \mu \mathrm{g} / 100 \mathrm{~g}$ of $\beta$ carotene, respectively, being highest in $\mathrm{T}_{3}$ followed by $\mathrm{T}_{2}, \mathrm{~T}_{1}$ and control upma. All three types of curry leaves supplemented upma had 30 to 60 times higher concentration of $\beta$-carotene than that of control upma.

Table.1 Proximate composition of CLP supplemented upma (\%, on dry weight basis)

\begin{tabular}{|c|c|c|c|c|c|c|}
\hline Treatments & Moisture* & $\begin{array}{c}\text { Crude } \\
\text { protein }\end{array}$ & Crude fat & $\begin{array}{c}\text { Crude } \\
\text { fibre }\end{array}$ & Ash & $\begin{array}{c}\text { Total } \\
\text { CHO's }\end{array}$ \\
\hline Control & $45.55 \pm 0.14$ & $11.10 \pm 0.02$ & $6.51 \pm 0.03$ & $1.31 \pm 0.01$ & $3.90 \pm 0.02$ & $31.63 \pm 0.08$ \\
\hline $\mathbf{T}_{\mathbf{1}}$ & $44.78 \pm 0.12$ & $11.44 \pm 0.02$ & $6.25 \pm 0.02$ & $1.77 \pm 0.02$ & $4.41 \pm 0.01$ & $31.39 \pm 0.10$ \\
\hline $\mathbf{T}_{\mathbf{2}}$ & $44.67 \pm 0.04$ & $11.73 \pm 0.01$ & $6.07 \pm 0.03$ & $2.06 \pm 0.04$ & $4.81 \pm 0.01$ & $30.63 \pm 0.11$ \\
\hline $\mathbf{T}_{\mathbf{3}}$ & $42.62 \pm 0.18$ & $12.07 \pm 0.02$ & $5.90 \pm 0.02$ & $2.29 \pm 0.02$ & $4.97 \pm 0.02$ & $32.16 \pm 0.05$ \\
\hline $\mathbf{C D}(\boldsymbol{P}<\mathbf{0 . 0 5})$ & 0.43 & 0.06 & 0.08 & 0.08 & 0.05 & 0.29 \\
\hline
\end{tabular}

Values are mean \pm SD of three independent determinations

Upma control: 100\% Semolina; $\mathrm{T}_{1}$ : CLP@5\%, $\mathrm{T}_{2}$ : CLP@ $1.5 \%, \mathrm{~T}_{3}$ : CLP@ 10\%; CLP: Curry Leaves Powder

* Moisture was analysed on fresh weight basis 
Table.2 Dietary fibre content of CLP supplemented upma (\%, on dry weight basis)

\begin{tabular}{|c|c|c|c|}
\hline Treatments & Soluble dietary fibre & \multicolumn{1}{|c|}{ Insoluble dietary fibre } & Total dietary fibre \\
\hline Control & $4.61 \pm 0.07$ & $14.52 \pm 0.09$ & $19.14 \pm 0.07$ \\
\hline $\mathbf{T}_{\mathbf{1}}$ & $5.26 \pm 0.07$ & $15.16 \pm 0.04$ & $20.48 \pm 0.04$ \\
\hline $\mathbf{T}_{\mathbf{2}}$ & $5.31 \pm 0.05$ & $16.84 \pm 0.08$ & $22.15 \pm 0.03$ \\
\hline $\mathbf{T}_{\mathbf{3}}$ & $6.10 \pm 0.05$ & $17.60 \pm 0.07$ & $23.70 \pm 0.11$ \\
\hline $\mathbf{C D}(\boldsymbol{P}<\mathbf{0 . 0 5})$ & 0.21 & 0.24 & 0.23 \\
\hline
\end{tabular}

Values are mean \pm SD of three independent determinations

Upma control: 100\% Semolina; $\mathrm{T}_{1}$ : CLP@5\%, $\mathrm{T}_{2}$ : CLP@7.5\%, T3: CLP@10\%; CLP: Curry Leaves Powder

Table.3 Beta-carotene content of CLP supplemented upma (on dry weight basis)

\begin{tabular}{|c|c|}
\hline Treatments & \multicolumn{1}{|c|}{$\boldsymbol{\beta}$-carotene $(\boldsymbol{\mu g} / \mathbf{1 0 0 g})$} \\
\hline Cpma \\
\hline Control & $159.18 \pm 0.05$ \\
\hline $\mathbf{T}_{\mathbf{1}}$ & $4,843.59 \pm 0.89$ \\
\hline $\mathbf{T}_{\mathbf{2}}$ & $7,185.89 \pm 0.01$ \\
\hline $\mathbf{T}_{\mathbf{3}}$ & $9,528.28 \pm 0.01$ \\
\hline $\mathbf{C D}(\boldsymbol{P}<\mathbf{0 . 0 5})$ & 0.19 \\
\hline
\end{tabular}

Values are mean \pm SD of three independent determinations

Upma control: 100\% Semolina; $\mathrm{T}_{1}$ : CLP@5\%, $\mathrm{T}_{2}$ : CLP@7.5\%, $\mathrm{T}_{3}$ : CLP@ 10\%; CLP: Curry Leaves Powder

\section{Plate.1 CLP supplemented Upma}

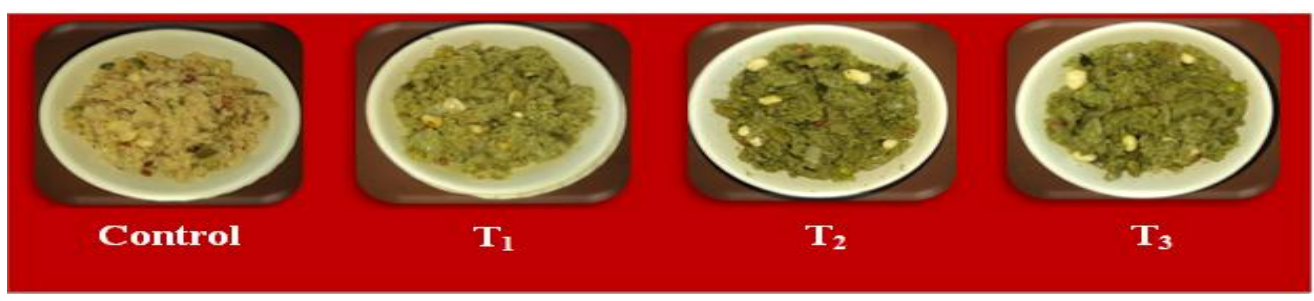

Figure.1 Mean sensory scores of CLP supplemented upma

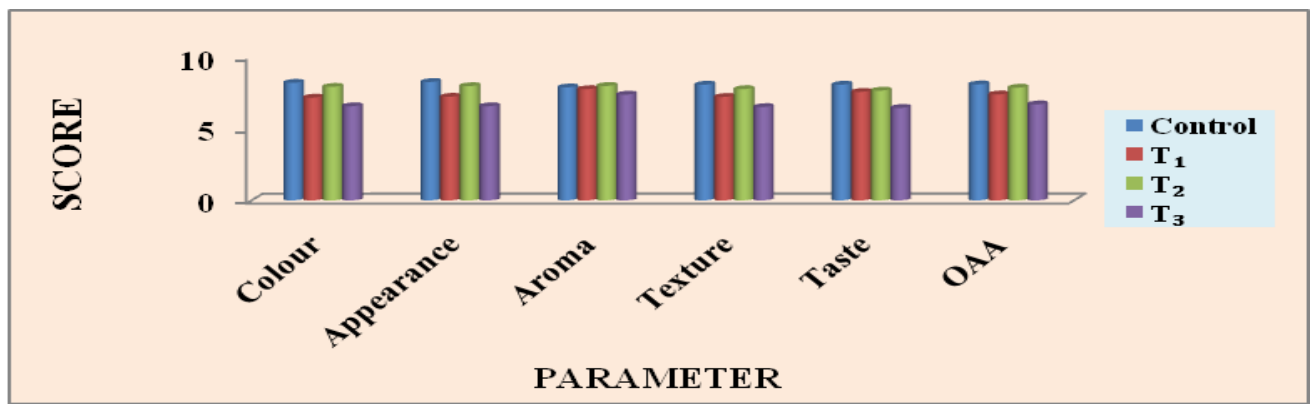


Exhaustive screening of literature on curry leaves indicated the fact that it is a popular remedy among the various ethnic groups, Vaidyas, Hakims and ayurvedic practitioners for cure of variety of ailments. Following the traditional and folk claims, very little efforts have been made by the researchers to explore the therapeutic potential of this plant. Results of sensory evaluation of upma observed in present study are in close agreement with those of earlier workers who also incorporated curry leaves powder at various levels i.e. 3, 4, 5 and 10 per cent in the development of chapatti, cooked rice and seasoned potatoes (Shanthala and Prakash 2005), mathri, uttapam, idli and lemon rice (Khatoon et al., 2011), buns (Sudha et al., 2014), biscuits (Drisya et al., 2015) idli (Chelliah et al., 2016), naan, vadiyan, bhatura, vada (Lal and Kaur 2017) and shrikhand (Jerish et al., 2020). It was observed that level beyond 8 per cent of curry leaves powder supplementation adversely affected the sensory acceptability of developed products.

Further, the results of proximate composition of CLP supplemented products of present study are supported by the findings of earlier investigators (Shanthala and Prakash 2005; Khatoon et al., 2011; Sudha et al., 2014; Drisya et al., 2015; Chelliah et al., 2016; Lal and Kaur, 2017; Jerish et al., 2020). The increased amounts of crude protein, ash and crude fiber in CLP supplemented products have been attributed due to higher contents of those in dried leaves powder. The addition of fresh and dehydrated curry leaves had significantly increased the dietary fibre content of the refined flour and whole wheat flour based buns i.e.10.8 to 14.4 per cent and 9.8 to 11.3 per cent, respectively (Sudha et al., 2014). Chelliah et al., (2016) revealed that incorporation of 5 per cent of curry leaves powder in to idli increased the dietary fibre content by 18.6 per cent as compared to control. Shanthala and Prakash (2005) found that the chapatti and seasoned potatoes with 5 per cent incorporation of curry leaves powder had increased the $\beta$-carotene by 37 per cent and 43 per cent, respectively than the control products. Other workers also found an increased $\beta$-carotene contentof products (mathri, uttapam, idli, lemon rice, buns and biscuits) prepared using CLP (Khatoon et al., 2011; Sudha et al., 2014; Wani and Sood 2014). Nandita and Prabhasanker (2009) stated that the natural antioxidants by some means enhanced the shelf-life of bakery products.

From the present study, it may be concluded that curry leaves powder are very good source of protein, dietary fibre and $\beta$-carotene. Curry leaves powder can be successfully incorporated up to 10 per cent to develop $\beta$ carotene rich upma without affecting the sensory acceptability except colour. Overall sensory acceptability of upma prepared using 7.5 per cent level of incorporation of CLP was found maximum, though all the upma were found acceptable. Beta carotene rich upma can be successfully developed by incorporating curry leaves powder. Besides $\beta$ carotene upma had significantly higher contents of ash, crude fibre and crude protein than the control products. Consumption of curry leaves powder supplemented products may improve the sub clinical deficiency of vitamin $\mathrm{A}$ in vulnerable group.

\section{References}

A.O.A.C. 2010. Official method of analysis. Association of Official Analytical Chemists. Washington, D.C.

Chandra-Hioe, M.V., Rahman, H.H. and Arcot, J. 2017. Lutein and $\beta$-Carotene in Selected Asian Leafy Vegetables. Journal of Food Chemistry and Nanotechnology, 3(3), 93-97.

Chandrika, U.G., Basnayake, B.M., 
Athukorala, I. Colombagama, P.W. and Goonetilleke, A. 2010. Carotenoid content and in vitro bio accessibility of lutein in some leafy vegetables popular in Sri Lanka. Journal of Nutritional Science and Vitaminology, 56, 203-207.

Chelliah, R., Ramakrishnan, S.R., Premkumar, D. and Antony, U. 2016. Bio-fortification and shelf-life extension of idli batter using curry leaves (Murraya koenigii). Journal of Food Science and Technology, 53(6), 2851-2862.

Drisya, C.R., Swetha, B.G., Velu, V., Indrani, D. and Singh, R.P. 2015. Effect of dried Murraya koenigii leaves on nutritional, textural and organoleptic characeteristics of cookies. Journal of Food Science and Technology, 52(1), 500-506.

Furda, I. 1981. Simultaneous analysis of soluble and insoluble dietary fibre. In: The analysis of dietary fibre in Food. (eds. W.P.T. James and O. Theander ) Marcel Dekker, New York, 163-172.

Garcia-Plazaola, J.I. and Becerril, J.M.N. 1999. A rapid high-performance liquid chromatography method to measure lipophilic antioxidants in stressed plants: simultaneous determination of carotenoids and tocopherols. Phytochemical Analysis, 10(6), 307313.

Jain, V., Momin, M. and Laddha, K. 2012. Murraya koenigii: An Updated Review. International Journal of Ayurvedic and Herbal Medicine, 2(4), 607-627.

Jerish, J.A., Gnanalaksshmi, K.S., Rani, K.V. and Manikkavasagan, I. 2020. Iron fortification of shrikhand using Murraya koenigii leaves extract. Indian Journal of Dairy Sciences, 73(1), 46-50.

Jimenez-Escrig, A., Jimenez-Jimenez, I.,
Sanchez-Moreno, C. and SauraCalixto, F. 2000. Evaluation of free radical scavenging of dietary carotenoids by the stable radical 2, 2diphenyl-1-picryl-hydrazyl. Journal of the Science of Food and Agriculture, 80, 1686-1690.

Khan, B.A., Braham, A. and Leelamma, S. 1997. Antioxidant effects of curry leaf, Murraya koenigii and mustard seeds, Brassica juncea in rats fed with high fat diet. Indian Journal Experimental Biology, 35(2), 148150.

Khatoon, J., Verma, A., Chacko, N. and Sheikh, S. 2011. Utilization of dehydrated curry leaves in different food products. Indian Journal of Natural Products and Resources, 2(4), 508-511.

Khoo, H.E., Prasad, N., Kong, K.W., Jiang, Y. and Ismail, A. 2011. Carotenoids and their isomers: colour pigments in fruits and vegetables. Journal of Molecular Structure, 16, 1710-1738.

Kumar, A.S. and Reddy, T.S.K. 2013. Importance of traditional system of medical- A Review. International Journal of Phytotherapy, 2, 1-6.

Lal, M. and Kaur, N. (2017) Nutritional and anti-nutritional composition of fermented food products developed by using dehydrated curry leaves (Murraya koenigii). International Journal of Food and Fermentation Technology, 7(2), 295-301.

Lal, M. and Kaur, N. (2019) Effect of processing on nutritional and antinutritional composition of curry leaves (Murraya koenigii). International Journal of Home Science, 5(3), 186190.

Nanditha, B. and Prabhasankar, P. 2009. Antioxidants in Bakery Products: A Review. Journal of Critical Reviews in Food Science and Nutrition, 49(1), 1- 
27.

Nayak, A., Mandal, S., Banerji, A. and Banerji, J. 2010. Review on chemistry and pharmacology of Murraya koenigii Spreng (Rutaceae). Journal of Chemical and Pharmaceutical Research, 2(2), 286-299.

Shanthala, M. and Prakash, J. 2005. Acceptability of curry leaf (Murraya koenigii) Incorporated products and attitude toward consumption. Journal of Food Processing and Preservation, 29, 33-44.

Singh, S., Omre, P.K. and Mohan, S.M. 2014. Curry leaves (Murraya koenigii Linn. Sprengal): A mircale plant. Indian
Journal of Scientific Research, 4(1), 46-52.

Sudha, M.L. Rajeswari, G. and Venkateswara, R.G. 2014. Chemical composition, rheological, quality characteristics and storage stability of buns enriched with coriander and curry leaves. Journal of Food Science and Technology, 51, 3785-93.

Wani, T.A. and Sood, M. 2014. Effect of incorporation of cauliflower leaf powder on sensory and nutritional composition of malted wheat biscuits. African Journal of Biotechnology, 13(9), 1019-1026.

\section{How to cite this article:}

Sonia, Varsha Rani, Sangeeta C. Sindhu and Josephine John. 2020. Curry Leaves: A Promising Ingredient for the Development of $\beta$-Carotene Rich Upma. Int.J.Curr.Microbiol.App.Sci. 9(09):

1326-1332. doi: https://doi.org/10.20546/ijcmas.2020.909.168 